Nevada

Environmental

Restoration.

Project

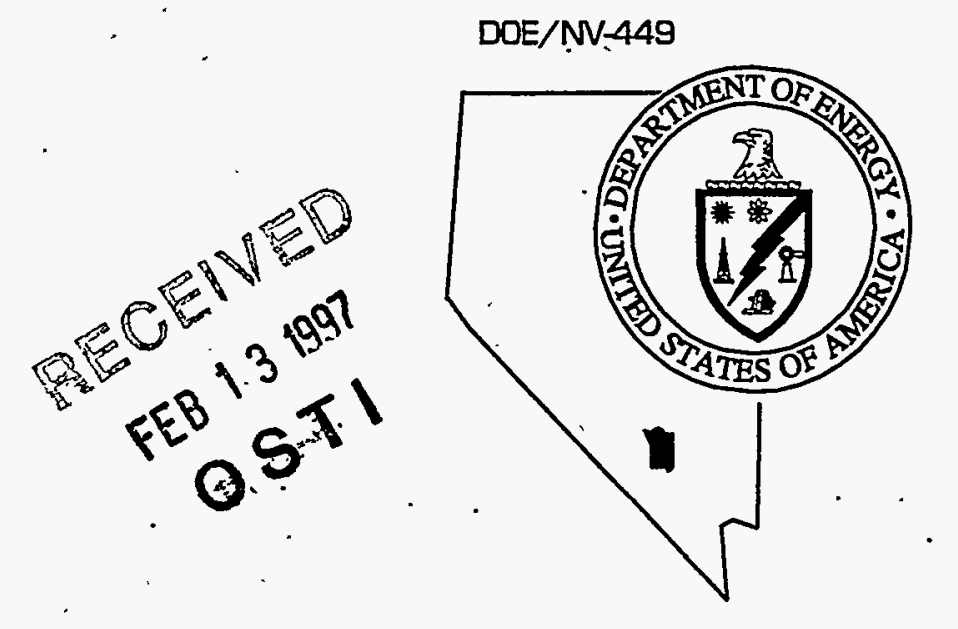

Fluid Management Plan

for the Project Shoal Area

Offsites Subproject

August 1996

\title{
MASTER
}

Environmental Restoration

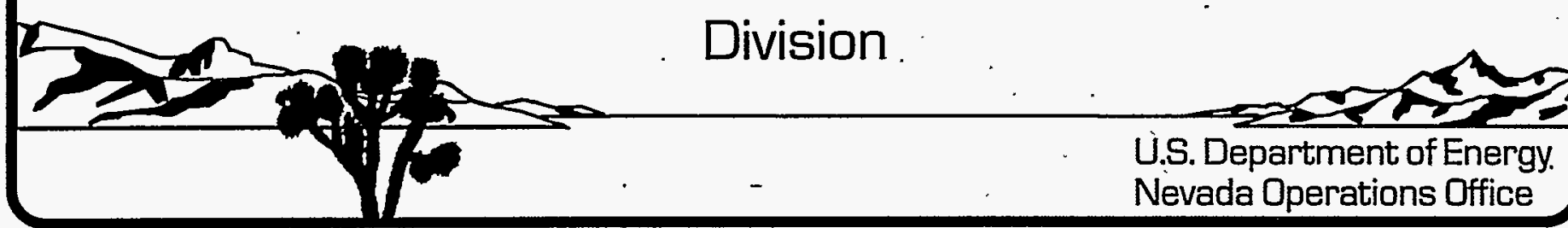




\section{FLUID MANAGEMENT PLAN FOR THE PROJECT SHOAL AREA OFFSITES SUBPROJECT}

DOE Nevada Operations Office

Las Vegas, Nevada

August 1996.

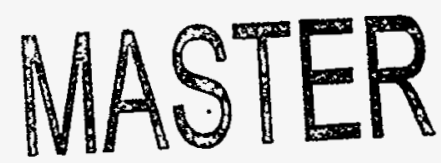

DISTRIBUTION OF RAIS DOCUMENT IS UNLIAITED 


\section{FLUID MANAGEMENT PLAN FOR THE PROJECT SHOAL AREA OFFSITES SUBPROJECT}

\section{DISCLAIMER}

This report was prepared as an account of work sponsored by an agency of the United States - Government. Neither the United States Government nor any agency thereof, nor any of their employees, makes any warranty, express or implied, or assumes any legal liability or responsibility for the accuracy, completeness, or usefulness of any information, apparatus, product, or process disclosed, or represents that its use would not infringe privately owned rights. Reference herein to any specific commercial product, process, or service by trade name, trademark, manufacturer, or otherwise does not necessarily constitute or imply its endorsement, recommendation, or favoring by the United States Government or any agency thereof. The views and opinions of authors expressed herein do not necessarily state or reflect those of the United States Government or any"agency thereof.

Approved:

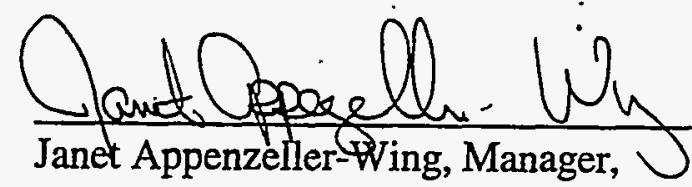

Date: $8 / 21 / 96$

Offsites Subproject

Approved:

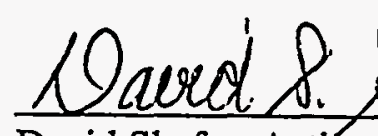

David Shafer, Acting Project Manager,

Nevada Environmental Restoration Project

Date: $8 / 21 / 96$ 


\section{DISCLAIMER}

Portions of this document may be illegible in electronic image products. Images are produced from the best available original document. 


\section{Table of Contents}

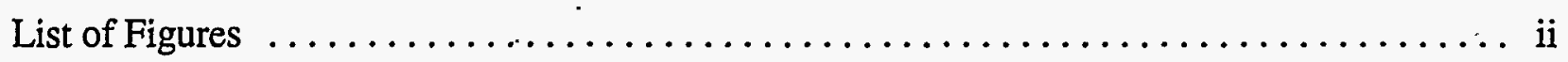

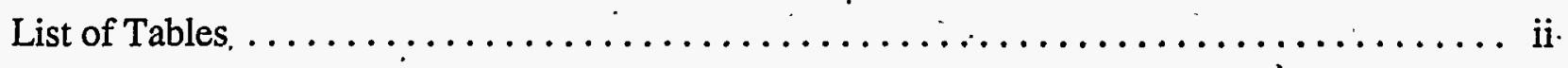

List of Acronyms and Abbreviations $\ldots \ldots \ldots \ldots \ldots \ldots \ldots \ldots \ldots \ldots \ldots \ldots \ldots \ldots \ldots$

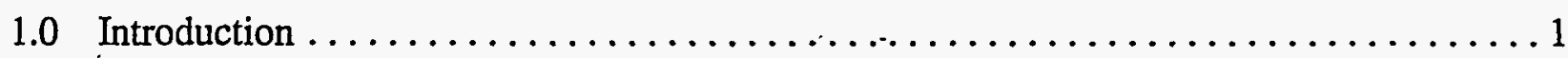

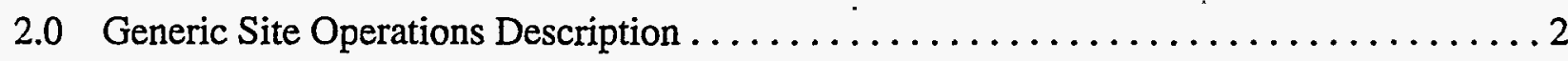

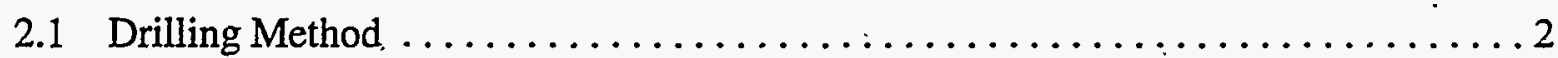

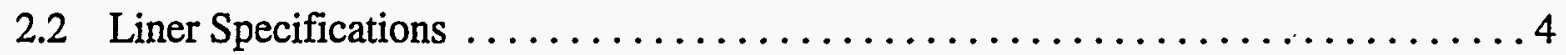

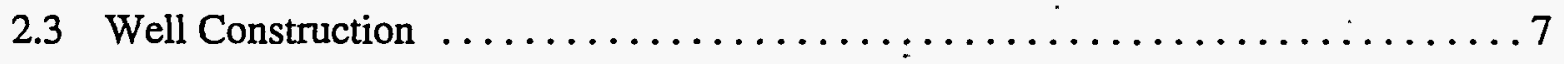

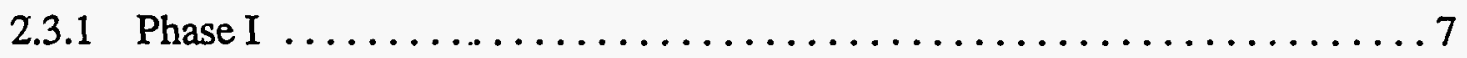

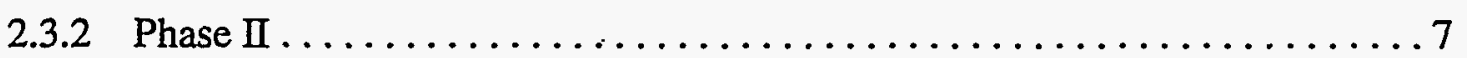

3.0 Fluid Monitoring Program $\ldots \ldots \ldots \ldots \ldots \ldots \ldots \ldots \ldots \ldots \ldots \ldots$

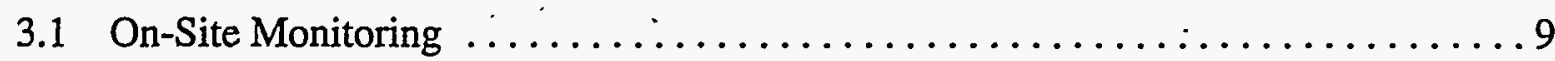

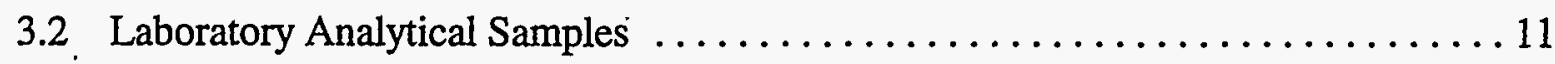

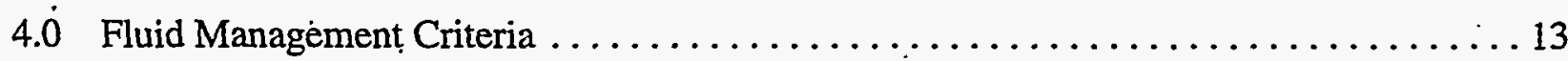

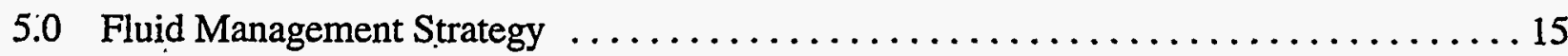

6.0 Fluid Manágement for Routine Monitoring $\ldots \ldots \ldots \ldots \ldots \ldots \ldots \ldots \ldots \ldots$

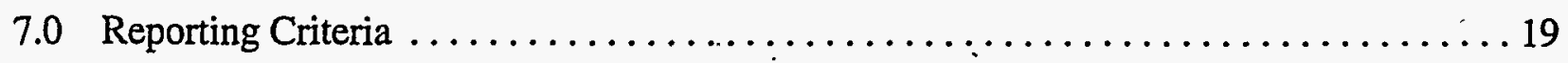

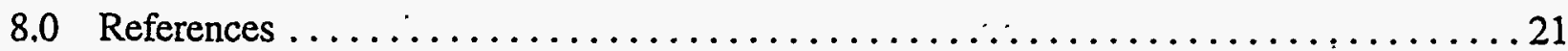




\section{List of Figures}

Figure

2-1 Generic Site Operations Schematic $\ldots 3$

2-2 Typical Double-Lined Sump Construction Schematic .6

2-3 Typical Single-Lined Sump Construction Schematic 8

3-1 On-Site Lead Monitoring Decision Process $\ldots \ldots \ldots \ldots \ldots \ldots \ldots \ldots \ldots \ldots \ldots$

5-1 Decision Diagram for Fluid Management $\ldots \ldots \ldots \ldots \ldots \ldots \ldots \ldots \ldots \ldots \ldots \ldots \ldots \ldots$

\section{List of Tables}

Table

2-1 Planned Well Locations $\ldots \ldots \ldots \ldots \ldots \ldots \ldots \ldots \ldots \ldots \ldots \ldots \ldots \ldots \ldots \ldots \ldots \ldots \ldots$

3-1 Analytical Laboratory Requirements for Fluid Management Samples

4-1 Fluid Management Decision Criteria Limits ..................... 14 


\section{List of Acronyms and Abbreviations}

$\begin{array}{ll}\text { CAIP } & \text { Corrective Action Investigation Plan } \\ \text { DOE } & \text { U.S. Department of Energy } \\ \text { DOE/NV } & \text { U.S. Department of Energy, Nevada Operations Office } \\ \text { EPA } & \text { U.S. Environmental Protection Agency } \\ \text { FFACO } & \text { Federal Facility Agreement and Consent } \text { Order } \\ \text { FMP } & \text { Fluid Management Plan } \\ \text { mL } & \text { Milliliter(s) } \\ \text { mg/L } & \text { Milligram(s) per liter } \\ \text { MCL } & \text { Maximum contaminant level } \\ \text { NDEP } & \text { Nevada Division of Environmental Protection } \\ \text { NDWS } & \text { Nevada Drinking Water Standards } \\ \text { NTS } & \text { Nevada Test Site } \\ \text { pCi/L } & \text { PicoCurie(s) per liter } \\ \text { ppm } & \text { Part(s) per million } \\ \text { PSA } & \text { Project Shoal Area } \\ \text { RCRA } & \text { Resource Conservation and Recovery Act } \\ \text { TD } & \text { Total depth }\end{array}$




\subsection{Introduction}

The U.S. Department of Energy, Nevada Operations Office (DOE/NV) has initiated the Offsites Subproject to characterize the hazards posed to human health and the environment as a result of underground nuclear testing activities at facilities other than the Nevada Test Site (NTS). A primary Subproject objective is to gather adequate data to characterize the various Subproject sites through the collection of surface and subsurface soil samples and by drilling several wells for the collection of groundwater data. The Project Shoal Area (PSA) is one of the Subproject's Nevada sites and is subject to the requirements set forth in the Federal.Facility Compliance Agreement and Consent Order (FFACO) (DOE, 1996a). In accordance with the FFACO, a Corrective Action Investigation Plan (CAIP) has been developed for work at the PSA (designated as Corrective Action Unit Number 416). This Fluid Management Plan (FMP) provides guidance for the management of fluids generated from wells constructed at the PSA. Long-term monitoring and future activities at the site, if required, will be set forth in additional documents as required by the FFACO.

The ultimate method for disposition of fluids generated by site operations depends upon sample analysis and process knowledge in relation to fluid management criteria. This FMP uses a fluid management decision strategy based on process knowledge and verification of process knowledge through laboratory analyses and/or field screening methodologies. Applicable process knowledge includes well construction, chemistry, geochemistry, the strata penetrated during drilling, and the possible presence of hazardous and radioactive constituents. Laboratory analyses of fluid (drilling fluid and groundwater) involves sample analyses to confirm process knowledge, and field screening provides for the timely detection of contamination indicators on-site (such as tritium for radionuclides and.lead for hazardous constituents) during drilling operations. Well site solids and liners will be managed as appropriate for the waste type as detailed in the CAIP, Section 5.0.

Section 2.0 of this document describes well site operations; Section 3.0 of this document discusses fluid management criteria; Section 4.0 includes the fluid monitoring program; Section 5.0 presents the fluid management strategy; Section 6.0 provides for fluid management during routine well monitoring; and Section 7.0 contains reporting criteria. 


\subsection{Generic Site Operations Description}

Up to four groundwater monitoring wells will be drilled at the PSA to determine groundwater flow and contaminant fate and transport in the underlying Sand Springs granite formation (AEC, 1970). These wells are planned for the vicinity of the underground nuclear test conducted at the site in 1963. Due to their proximity to the event, the wells may yield groundwater contaminated with radionuclides and other possible constituents from the test. Figure 2-1 represents a generic layout for well-site operations. Orie single-lined and one double-lined sump will be constructed at each drill pad. The single-lined sump will be used to contain uncontaminated fluids. The double-lined sump will be used to contain contaminated fluids and will be outfitted with a leak detection system.

The proposed locations of the four wells are listed in Table 2-1.

Table 2-1

Planned Well Locations

\begin{tabular}{|c|c|c|c|c|}
\hline Well No. & Township & Range & Section & Quarter - Quarter \\
\hline \hline 1 & $16 \mathrm{~N}$ & $32 \mathrm{E}$ & 34 & SE of NW \\
\hline 2 & $16 \mathrm{~N}$ & $32 \mathrm{E}$ & $\cdots 34$ & SW of SW \\
\hline 3 & $15 \mathrm{~N}$ & $32 \mathrm{E}$ & 3 & NE of NE \\
\hline 4 & $15 \mathrm{~N}$ & $32 \mathrm{E}$ & 3 & NW of NW \\
\hline
\end{tabular}

\subsection{Drilling Method}

Well design calls for an 8-inch diameter borehole drilled to an anticipated total depth (TD) of 1,500 feet. Casing (5.5-inch diameter) will be installed in the unsaturated portion of the borehole. The surface casing will be 8.625 -inch internal diameter carbon steel casing, grouted in place, and installed in a 14-inch diameter hole. The casing will be stubbed out above the surface and fitted with a locked cap in accordance with State of Nevada drilling regulations.

The planned drilling method is air rotary with a down-hole hammer using no additives to the drilling medium (air). If the hole will not stay open using just air, then drilling with foam will be 
FMP for Shoal

Section: 2.0

Revision: 0 .

Date: $08 / 21 / 96$

Page 3 of 21
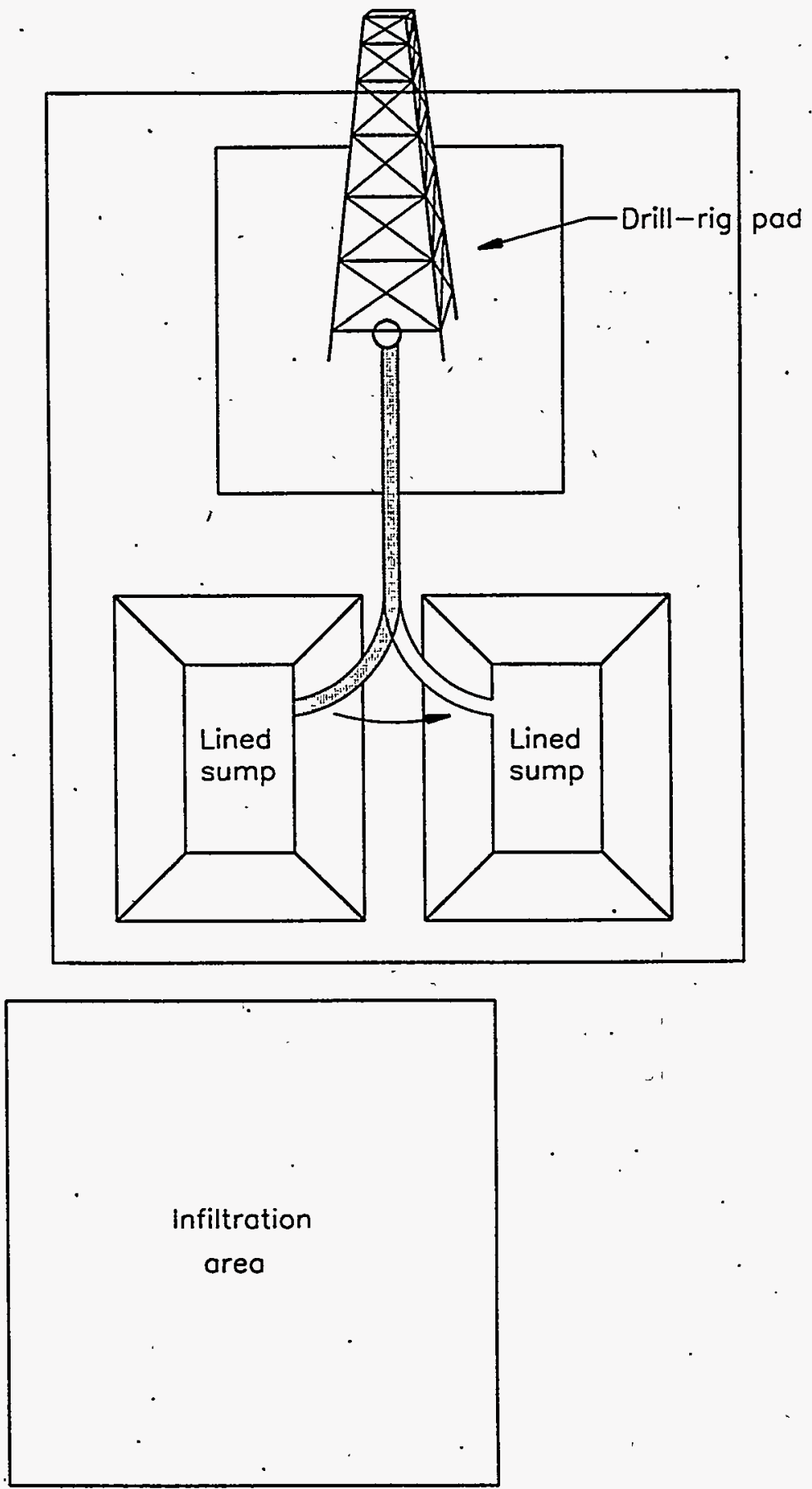

NOT TO SCALE

Figure 2-1

Generic Site Operations Schematic 
tried first. Polymer and/or foam additives may be used to stabilize hole conditions. If this technique does not work, then mud rotary methods may be used. Make-up water, if required, will be obtained from the existing well HS-1, located approximately 3 miles east of the site in Fairview Valley. This well was originally drilled to provide water for the PSA in the early 1960s. It is currently used by a private party during the winter to provide water for livestock; permission to use the well for the current drilling operation has been granted. The well is sampled annually for radionuclides by the U.S. Environmental Protection Agency (EPA) and will be sampled for fluid management parameters prior to its being used for this subproject. A potential alternate well has also been identified as a source of make-up water and a sample collected and analyzed for fluid management parameters. This well is located at the Kennecott Rawhide Mine, located approximately 15 miles south of the project site. The source of this water is a well at Dead Horse Springs in the northern portion of Gabbs Valley.

\section{$2.2 \quad$ Liner Specifications}

\section{Double-Lined Sumps}

One double-lined sump with a leak detection system will be constructed at each drill pad. Drilling fluid circulation returns are to be diverted to the sump just prior to reaching the water table, if contamination is expected, or prior to the return fluid reaching a predetermined tritium concentration. The purpose of the double lined sump is to provide adequate containment of mixed waste which may be produced during the drilling operations. Main features of the typical double-lined sump construction are described below:

- Dirt work and preparation for liner installation - The typical standard size sump is 6 feet deep with a 15-foot by 15 -foot square bottom and a 2 to 1 slope on the sides. This makes the outside perimeter of the sump approximately 40 feet by 40 feet. The preferred construction method is simply to excavate the native soil and contour the slopes. However, depending on the hardness of the ground and the presence of rocks or boulders, cut-and-fill techniques may be used when necessary. The bottom of the sump is sloped slightly to one side into a leak detection trench. The trench is about 1 foot deeper than the base of the sump. The leak detection trench is sloped to one corner of the sump. Prior to liner installation any rocks are removed from the bottom or slopes of the sump and geotextile material will be installed over the complete sump area to provide protection from punctures or tears.

- Liner installation - In the standard double lined sump system the primary liner is the liner in contact with the liquids and the secondary liner is a back-up to the primary liner. The first geomembrane placed on top of the geotextile will be Hypalon ${ }^{\mathrm{TM}}$. The minimum thickness of this geomembrane is typically 36 mils. Liner material will be prefabricated at the supplier 
prior to delivery to the site. The secondary liner will be placed in the bottom of the leak detection trench, and washed 3/8- to 3/4-inch gravel will be used to fill the pit after the bottom of the leak detection pipe has been installed: A 4-inch polyvinyl chloride leak detection pipe will provide access to the leak detection trench or pit for measuring fluid accumulation between the two liners and for pumping the contents of the trench or pit. Prior to placement of the primary liner a layer of geo-webbing, geo-netting, or geotextile will be placed on top of the secondary liner and pea gravel in the bench to provide for separation and allow free flow of liquids between the primary and secondary liners." The access pipe, typically plastic or fiberglass, is slotted at the bottom to allow free entry of any fluid which accumulates in the leak detection trench or pit. The leak detection pipe is run through the primary liner at a point near the top of the slope and the liner is sealed around the circumference of the pipe. To anchor the outer edges of the liners, a trench, approximately $11 / 2$ feet wide by 1 foot deep, is dug around the perimeter of the sump. The edge of the liners are laid in the bottom of the trench and the trench is backfilled with native material. A typical double-lined sump construction schematic is provided in Figure 2-2.

- Wildlife escape ladder - A section of "snow fence" is lain on the sump slope on top of the primary liner on one side of the sump and anchored at the top in the liner footing trench and by sand bags at the bottom. Since maintaining a footing on the lined sump slope is very. difficult, this provides a means for wildlife to egress from the sump.

- Fencing - After the liners are in place and the liner footing trench backfilled, the fence is installed completely around the perimeter of the sump. This fence serves as barrier to keep wildlife out of the sump and also serves a control fence around an exclusion zone once contaminated fluids have been introduced into the sump. The fence is typically plastic "snow fence" attached to 6-foot steel posts driven into the ground.

- Flagging - After the fence has been installed flagging material is strung across the sump both lengthwise and diagonally and anchored to the fence posts. The flagging serves as a deterrent to water fowl or other birds from entering the sump.

\section{Single-Lined Sumps}

Single-lined sumps are constructed much the same as described above for the double-lined sumps.

- Dirt work and preparation for liner installation - The dirt work and the preparation for . installation of the liner is the same as the double-lined sump with the exception of the construction of the leak detection trench or pit within the sump. Single-lined sump sizes are typically 25 by 25 feet at the base and 50 by 50 feet at the perimeter.

- Liner installation - Liner installation for the single-lined sump is typically the same as the double-lined sump using the same liner material and using a trench around the perimeter of the sump to anchor the edge of the liner. 


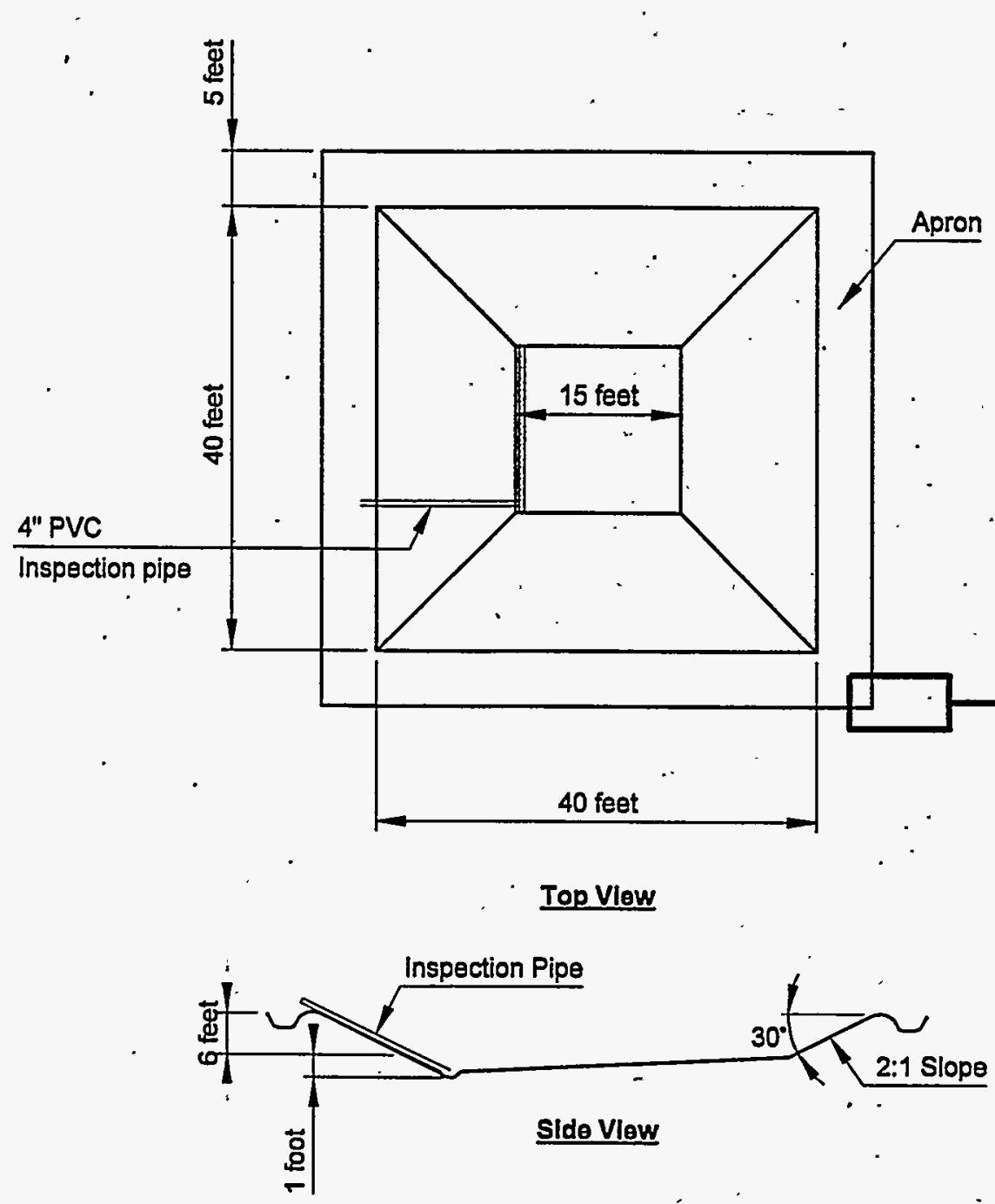

Date: $08 / 21 / 96$

Page 6 of 21

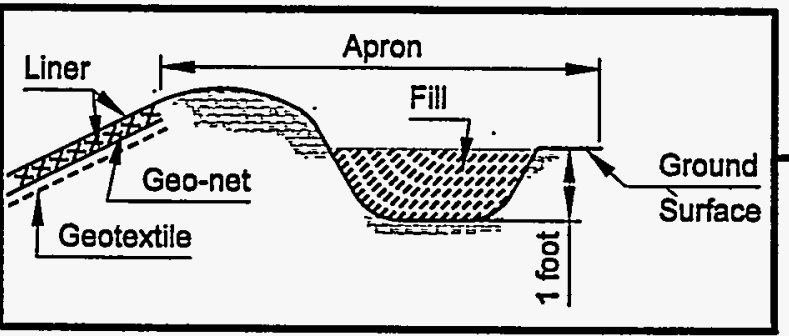

Inset Vlew

Noto:

Liners are 55- by 55-foot flat sheet of 36-mil (0.036-inch) Hypalon.

Leak detection trench filled with $+1 / 2-3 / 4^{\prime \prime}$ gravil.

Figure 2-2

Typical Double-Lined Sump Construction Schematic 
- Wildlife escape ladders, fencing, and flagging - Construction of these three features of the single-lined sump is the same as the double-lined sump.

A typical single-lined sump construction schematic is provided in Figure 2-3.

\subsection{Well Construction}

Well construction activities can be divided into two main operative phases: Phase I, which includes vadose zone and saturated zone drilling, and Phase II, which inciudes initial well development, aquifer testing, well completion, final development/testing, and initial sampling. A description of each phase is provided in the following sections. In general, Phase I activities are those activities which advance the drill hole; Phase $I$ activities are those activities which convert the borehole into a well. Routine monitoring (which occurs on a scheduled, periodic basis) is discussed in Section 6.0 of this document. Management of solids resulting from drilling operations is discussed in the CAIP.

\subsubsection{Phase I}

Phase I activities include all operations associated with advancement of the borehole. Unsaturated zone, or vadose zone, drilling is conducted above the permanent groundwater table. Fluids produced dưring vadose-z̧one drilling are mainly rock cuttings and drilling fluids (air and make-up water, if necessary).

Saturated zone drilling begins once the water table is reached and continues through the saturated zone to the desired TD. Groundwater, cuttings, and any necessary drilling fluids are produced during saturated-zone drilling.

\subsubsection{Phase II}

Phase II begins when TD is reached and borehole advancement is complete. Once borehole advancement has ceased, the borehole may then be developed to remove residual cuttings and any drilling fluids which may have invaded the formation during drill advancement. Note that due to borehole conditions, not all wells undergo initial well development.

Depending on borehole stability, aquifer testing may be conducted after the well is initially developed, prior to its completion. Phase $\Pi$ also includes well completion, final well development, and final aquifer testing. At this time, only slug testing is planned. 


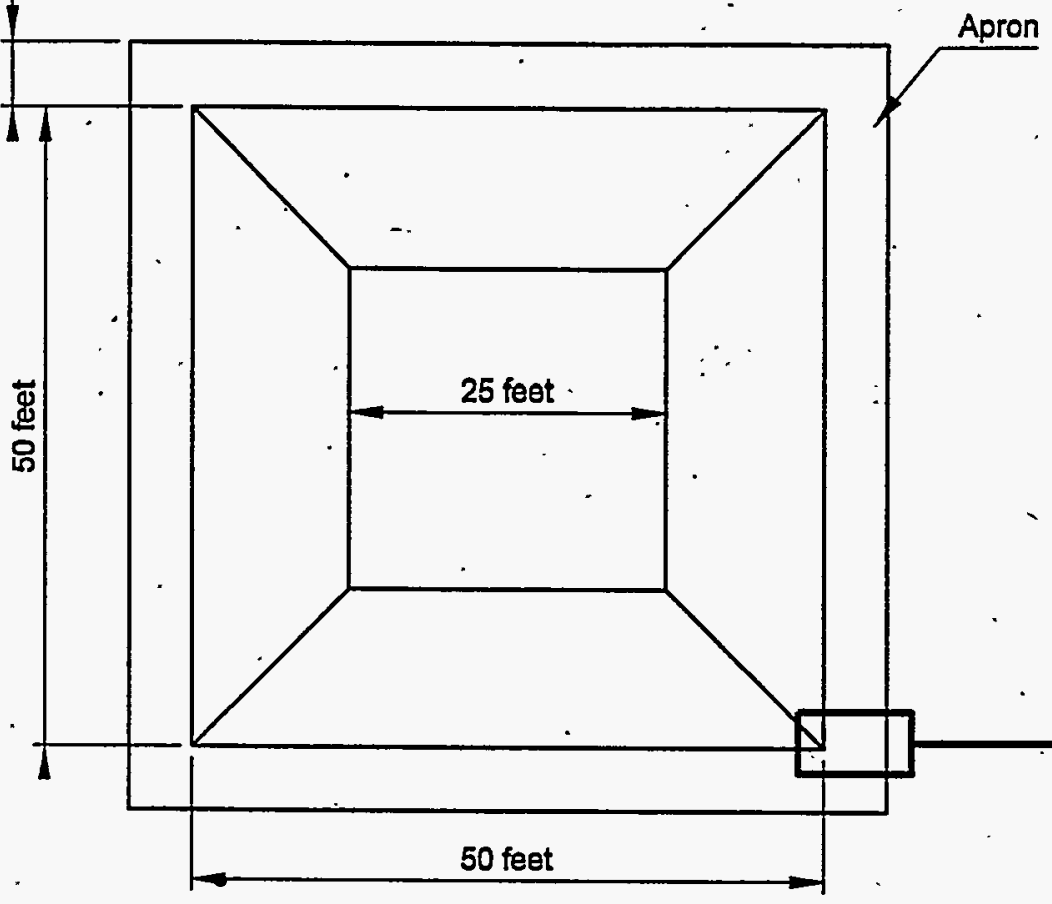

Top Vlow

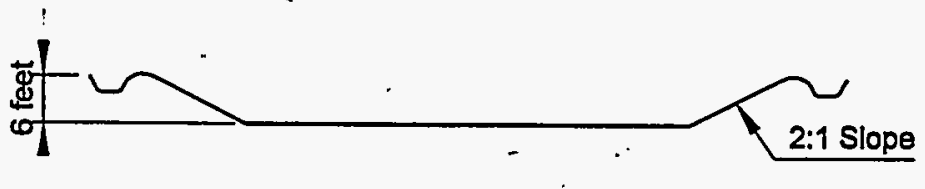

Side Vlaw

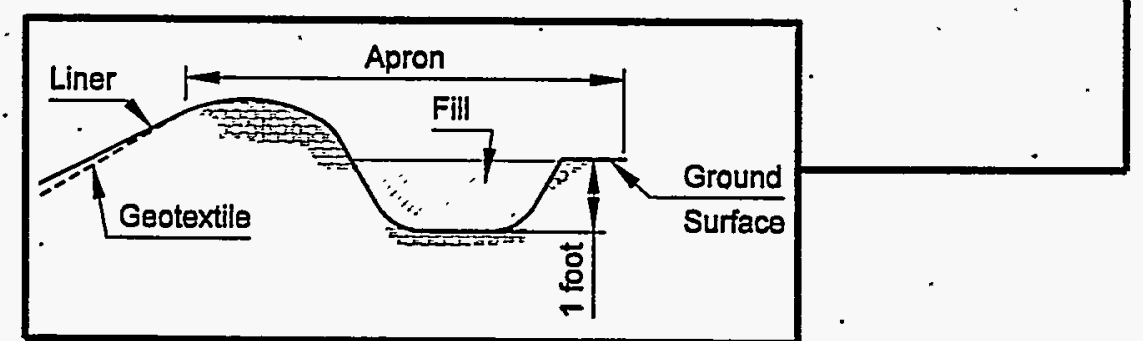

Inset Vlew

Note:

Liner is a 65- by 65-foot flat sheet of 36-mil (0.036-inch) Hypalon." 


\subsection{Fluid Monitoring Program}

Fluid will be characterized through on-site field monitoring of well discharge lines and sump contents and by an off-site independent laboratory analysis of the sump contents.

\subsection{On-Site Monitoring}

Fluids generated during drilling will be analyzed for.lead and tritium while the drill hole is being advanced. During periods when the hole is not being advanced, during circulation or while attempting to establish circulation, monitoring is not required.

Tritium will be monitored hourly while the drill hole is being advanced by using a liquid scintillation counter, following approved operating procedures and manufacturer's recommended instructions for use. Lead will be monitored at least once every eight hours while the drill hole is being advanced with a digital voltameter, or by the colorimetric method or other approved method following approved operating procedures and the manufacturer's recommended instructions for use. These tritium and lead samples will be collected from the blooie line. Figure 3-1 outlines the decision process for on-site lead monitoring during borehole advancement.

If a scheduled lead sample (taken every eight hours) reveals concentrations equal to or above 3 parts per million (ppm), a confirmatory sample from the blooie line will be taken immediately. If this sample result indicates lead levels lower than $3 \mathrm{ppm}$, another blooie line sample will be taken and if shown to confirm a level less than $3 \mathrm{ppm}$, the eight-hour blooie line sample schedule will be reinstated. If either confirmatory sample indicates a lead level equal to or greater than $3 \mathrm{ppm}$, both of the following two actions shall be taken:

(1) Blooie line lead monitoring shall increase to hourly. The hourly sampling shall continue until at least three consecutive hourly samples indicate that the lead level from the blooie line is less than $3 \mathrm{ppm}$. At this point, a monitoring schedule of once every eight hours may resume.

(2) $\dot{A}$ composite sump sample shall be taken immediately. This composite sample shall be collected from the sump to which the blooie line discharged at the time of the original sample (the first blooie line sample showing a lead level equal to or greater than $3 \mathrm{ppm}$ ) and all other sumps to which the suspect fluid may have been transferred. The composite sample will be screened on-site for lead and tritium. 


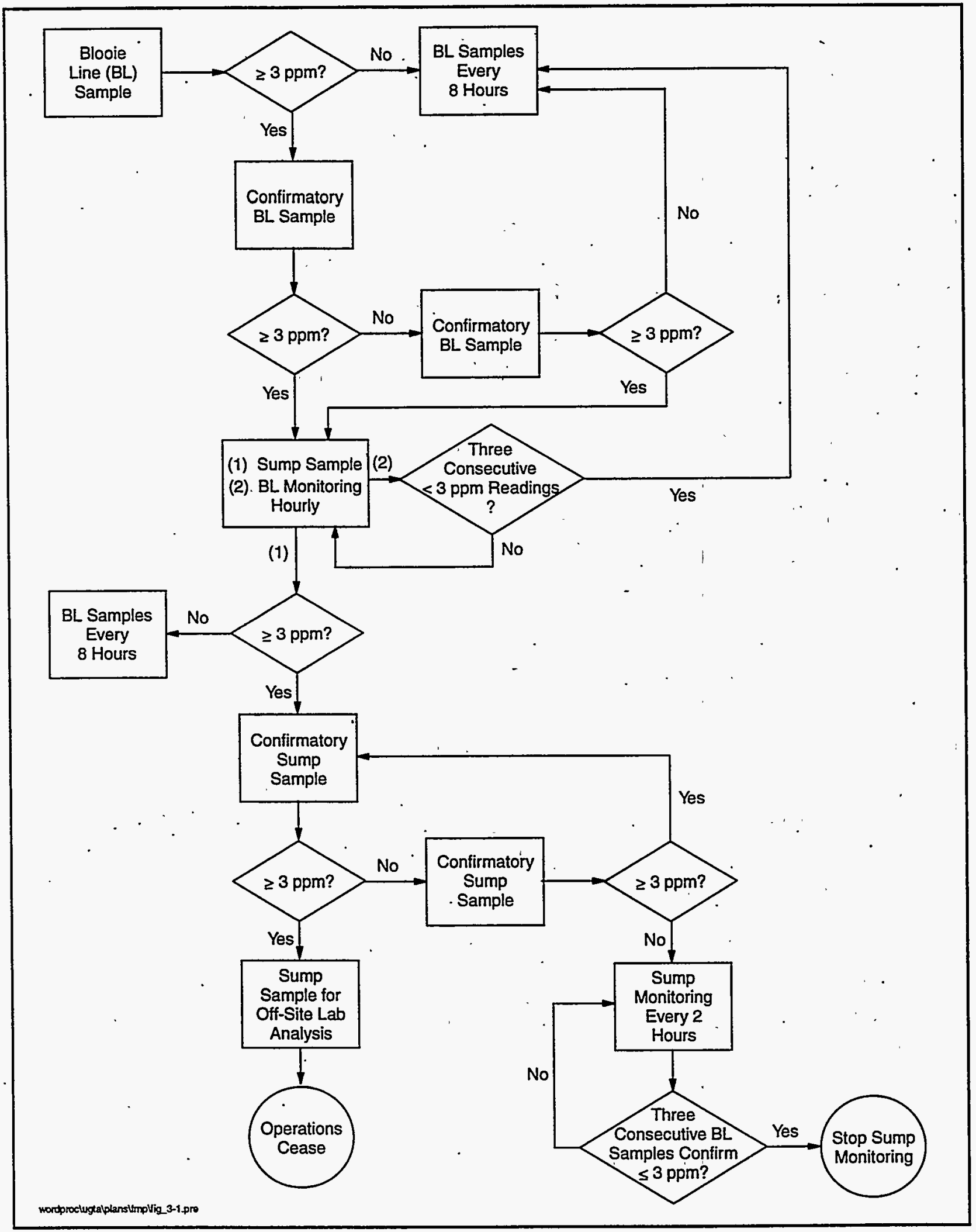

Figure 3-1 
If the lead concentration from this sump sample is less than $3 \mathrm{ppm}$, scheduled eight-hour blooie line monitoring will be resumed. If the on-site monitoring of the sump contents indicate a level at or above $3 \mathrm{ppm}$, an additional sump sámple will be collected and analyzed on site. If this confirmatory sump sample indicates elevated levels, an additional-sump sample will be taken and sent off site for laboratory analysis with a quick turnaround time requested from the laboratory. If the laboratory analytical sample indicates levels below $3 \mathrm{ppm}$, another confirmatory sump sample will be collected and analyzed on site. If this confirmatory sample indicates lead levels above or equal to $3 \mathrm{ppm}$, another sump sample shall be collected and analyzed in accordance .with Figure 3-1. If the sump lead level remains at or above $3 \mathrm{ppm}$ but below $5 \mathrm{ppm}$, drilling may continue, with sump and blooie line samples collected every 2 hours until the lead level increases to near 5 ppm or decreases to below 3 ppm. If the confirmatory sample indicates a lead level below 3 ppm, sump monitoring will continue once every two hours until three blooie line samples consistently indicate that blooie line discharge contains lead at a level less than $3 \mathrm{ppm}$. Once the blooie line discharge is confirmed to be consistently below $3 \mathrm{ppm}$, sump monitoring may cease and regularly scheduled blooie line monitoring resumed. If on-site monitoring indicates that the sump lead level is approaching $5 \mathrm{ppm}$, drilling shall stop until it can be determined that continuing would not generate a hazardous waste.

\subsection{Laboratory Analytical Samples}

A sump sample shall be collected and analyzed by an off-site laboratory prior to routing fluids to an infiltration area or the ground surface. If fluids are being added to the sumps (i.e., during borehole advancement [Phase $\Pi$ ] or during well completion activities [Phase II]), a sump sample does not need to be collected. However, once operations that affect sump volume have ceased, a sump sample must be collected for laboratory analysis. The sample will be analyzed for the parameters listed in Table 3-1, and a 14-day turnaround time will be requested for laboratory analysis. If laboratory results indicate that the lead concentration is at a hazardous or mixed . waste level, the Nevada Division of Environmental Protection (NDEP) will be notified. 
Table 3-1

Analytical Laboratory Requirements for Fluid Management Samples

\begin{tabular}{|c|c|c|c|c|c|c|}
\hline Parameter & $\begin{array}{l}\text { Analytical } \\
\text { Method }\end{array}$ & Container Type ${ }^{a}$ & Preservative & $\begin{array}{l}\text { Maximum Holding } \\
\text { Time }\end{array}$ & $\begin{array}{c}\text {. Reporting } \\
\text { Detection Limit }\end{array}$ & $\begin{array}{c}\text { Fluid Quality } \\
\text { Objectives }\end{array}$ \\
\hline $\begin{array}{c}\text { Total Metals: } \\
\text { Arsenic } \\
\text { Barium } \\
\text { Cadmium } \\
\text { Chromium } \\
\text { Lead } \\
\text { Selenium } \\
\text { Silver } \\
\text { Mercury }\end{array}$ & $\begin{array}{l}\text { SW-846 6010 } \\
\text { SW-846 6010 } \\
\text { SW-846 6010 } \\
\text { SW-846 6010 } \\
\text { SW-846 6010 } \\
\text { SW-846 6010 } \\
\text { SW-846 6010 } \\
\text { SW-846 7470 }\end{array}$ & $\begin{array}{l}\text { (1) } 500-\mathrm{mL}^{\mathrm{b}} \\
\text { polyethylene or } \\
\text { amber glass }\end{array}$ & $\begin{array}{c}\mathrm{HNO}_{3} \text { to } \mathrm{pH}<2 \\
\text { Cool to } 4^{\circ} \mathrm{C}\end{array}$ & $\begin{array}{l}180 \text { Days } \\
28 \text { days }\end{array}$ & $\begin{array}{l}0.1 \mathrm{mg} / \mathrm{L}{ }^{c} \\
0.1 \mathrm{mg} / \mathrm{L} \\
0.01 \mathrm{mg} / \mathrm{L} \\
0.1 \mathrm{mg} / \mathrm{L} \\
0.2 \mathrm{mg} / \mathrm{L} \\
0.001 \mathrm{mg} / \mathrm{L} \\
0.05 \mathrm{mg} / \mathrm{L} \\
0.1 \mathrm{mg} / \mathrm{L}\end{array}$ & $\begin{array}{l}0.5 \mathrm{mg} / \mathrm{L} \\
20 \mathrm{mg} / \mathrm{L} \\
0.05 \mathrm{mg} / \mathrm{L} \\
1.0 \mathrm{mg} / \mathrm{L} \\
0.5 \mathrm{mg} / \mathrm{L} \\
0.02 \mathrm{mg} / \mathrm{L} \\
0.5 \mathrm{mg} / \mathrm{L}: \\
1.0 \mathrm{mg} / \mathrm{L}\end{array}$ \\
\hline $\begin{array}{l}\text { Gross Alpha } \\
\text { Gross Beta }\end{array}$ & $\begin{array}{c}\text { EERF } 00-02^{d} \\
\text { or } \\
\text { EPA' } 900.0 \\
\text { or } \\
\text { SW-846-9310 }\end{array}$ & $\begin{array}{c}\text { (1) 1-liter } \\
\text { polyethylene }\end{array}$ & $\begin{array}{l}\text { Lab Filtration. } \\
\text { or } \\
\text { Field Filtration, } \\
\mathrm{HNO}_{3} \text { to } \mathrm{pH}<2 \text {, }\end{array}$ & 180 Days & $\begin{array}{l}<15 \mathrm{pCi} / \mathrm{L}^{\circ} \\
<15 \mathrm{pCi} / \mathrm{L} .\end{array}$ & $\begin{array}{l}150 \mathrm{pCi} / \mathrm{L} \\
500 \mathrm{pCi} / \mathrm{L}\end{array}$ \\
\hline Tritium & $\begin{array}{l}\text { EPA } 906.0 \\
\text { or equivalent }\end{array}$ & $\begin{array}{l}\text { (1) } 500-\mathrm{mL} \\
\text { polyethylene or } \\
\text { amber glass }\end{array}$ & $\begin{array}{l}\text { Lab filtration } \\
\text { or } \\
\text { Field Filtration, } \\
\text { Cool to } 4^{\circ} \mathrm{C}\end{array}$ & 180 Days & 3,000 pCi/L & $\quad 20,000 \mathrm{pCi} / \mathrm{L}$ \\
\hline
\end{tabular}

${ }_{b}^{a}$ Volume specifications are based on sample compositing requirements.

Milliliter

dMilligram per liter

OPlcocurie per liter 


\subsection{Fluid Management Criteria}

Based on process knowledge, the following parameters were selected for establishing drilling fluid quality relative to Nevada Drinking Water Standards (NDWS): arsenic, barium, cadmium, chromium, lead, mercury, selenium, silver, tritium, gross alpha; and gross beta. The fluid quality objectives are based on dissolved constituents and.indicate the thresholds at which fluid management decisions are made. These objectives are as follows:

$<5 \mathrm{x}$ NDWS = Fluids may be conveyed to the ground surface/infiltration area

5 to $10 \mathrm{x}$ NDWS = Fluids may be conveyed to a constructed infiltration area 10 to $50 \times$ NDWS $=$ Contain fluids

50 to $99 \times$ NDWS $=$ Confirm the concentration of hazardous constituents

$z 100 \times$ NDWS = Manage in accordance with state of Nevada hazardous waste criteria (for Resource Conservation and Recovery Act [RCRA]-regulated parameters only)

Table 4-1 outlines the decision criteria limits used to manage fluids covered under this plan. The PSA is rich in naturally occurring metals such as arsenic and mercury. Therefore, results from Well HS-1 will be used to establish background levels for metals which will be added to the fluid management objectives for purposes of decision making, i.e., objectives will be the NDWS plus naturally occurring background levels for metals.

Although the decision criteria are based on the concentration of dissolved constituents, samples will be analyzed for total concentrations with the exception of radiological parameters. As long as the total concentrations remain below the decision thresholds, the dissolved fractions are assumed to be below thresholds. In the event analyses indicate total levels at or near decision thresholds, fluids will be resampled, filtered, preserved, and analyzed for dissolved fractions to confirm management decisions based on fluid quality. 
Table 4-1

Fluid Management Decision Criteria Limits

\begin{tabular}{|c|c|c|c|}
\hline FMP Parameters & $\begin{array}{c}\text { NDWS Standard } \\
\text { (micrograms per liter) }\end{array}$ & $\begin{array}{c}5 X \text { MCL Limit } \\
\text { (micrograms per liter) }\end{array}$ & $\begin{array}{c}\text { 10X MCL Limit } \\
\text { (micrograms per liter) }\end{array}$ \\
\hline Arsenic & 50 & 250 & 500 \\
\hline Barium & 2,000 & 10,000 & 20,000 \\
\hline Cadmium & 5 & 25 & 50 \\
\hline Chromium & 100 & 500 & 1,000 \\
\hline Lead & 50 & 250 & 500 \\
\hline Selenium & 50 & 250 & 500 \\
\hline Silver & 100 & 500 & 1,000 \\
\hline Mercury . & 2 & .10 & 20 \\
\hline Gross Alpha & $15 \mathrm{pCi} / \mathrm{L}^{\mathrm{d}}$ & $75 \mathrm{pCi} / \mathrm{L}$ & $150 \mathrm{pCi} / \mathrm{L}$ \\
\hline Gross Beta & $50 \mathrm{pCi} / \mathrm{L}$ & $250 \mathrm{pCi} / \mathrm{L}$ & $500 \mathrm{pCi} / \mathrm{L}$ \\
\hline Tritium & $20,000 \mathrm{pCi} / \mathrm{L}$ & $100,000 \mathrm{pCi} / \mathrm{L}$ & $200,000 \mathrm{pCi} / \mathrm{L}$ \\
\hline
\end{tabular}

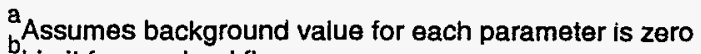

Limit for overiand flow

Limit for infiltratlon area

PicoCurie per liter

$\mathrm{MCL}=$ Maximum Contaminant Level 


\subsection{Fluid Management Strategy}

Fluids generated while the borehole is being advanced will be routed to a lined sump for containment prior to final disposition. Depending upon operational requirements and fluid quality, fluids may be:

- Routed to the ground surface

- Routed to a constructed infiltration area

- Routed to another lined sump

- Retained in lined sumps pending evaporation

- Transported to a lined sump or infiltration area at another location

- Transported to a treatment, storage, or disposal facility

- Routed into portable (i.e., Baker) tanks

In no event will fluids be routed or transported to an infiltration area or the ground surface if fluid quality parameters, as provided in Section 4.0 of this document, are not met. Figure 5-1 illustrates the general decision-flow process for the management of fluids under this FMP, assuming overland flow is not used for fluid disposition. If overland flow is used, the criteria for routing fluids out of the sump will be less than or equal to 5 times the NDWS, rather than less than or equal to 10 times the NDWS.

Fluids that do not meet criteria specified in Section 4.0 (i.e., greater than ten times the NDWS) will be retained in lined sumps; transported to another lined sump; transported to a treatment, storage, or disposal facility; or routed into portable tanks for final disposition. As specified in Section 3.2 of this FMP, sump contents will be sampled after the well is completed and analyzed by an off-site laboratory with results requested within 14 days of sample receipt. Data will be examined to determine fluid management requirements within 10 working days of receipt. Fluids documented to be below the RCRA limits, but above 10 times the NDWS, will be allowed to evaporate in lined sumps and the solids retained on site for future management as industrial solid waste in accordance with the CAIP (DOE, 1996c). Fluids documented to be above RCRA limits would result in the suspension of operations and would be managed as hazardous (or mixed) waste in accordance with state of Nevada hazardous waste regulations and DOE Orders. NDEP will be immediately notified if fluids are documented to be hazardous or mixed waste. The fluids will be pumped from the lined sumps and transported to an appropriate storage area such as the NTS Hazardous Waste Storage Pad (for hazardous waste) or the NTS Transuranic -Waste Storage Pad (for mixed waste). Alternatively, hazardous waste may be transported directly to a permitted commercial treatment, storage, or disposal facility. 


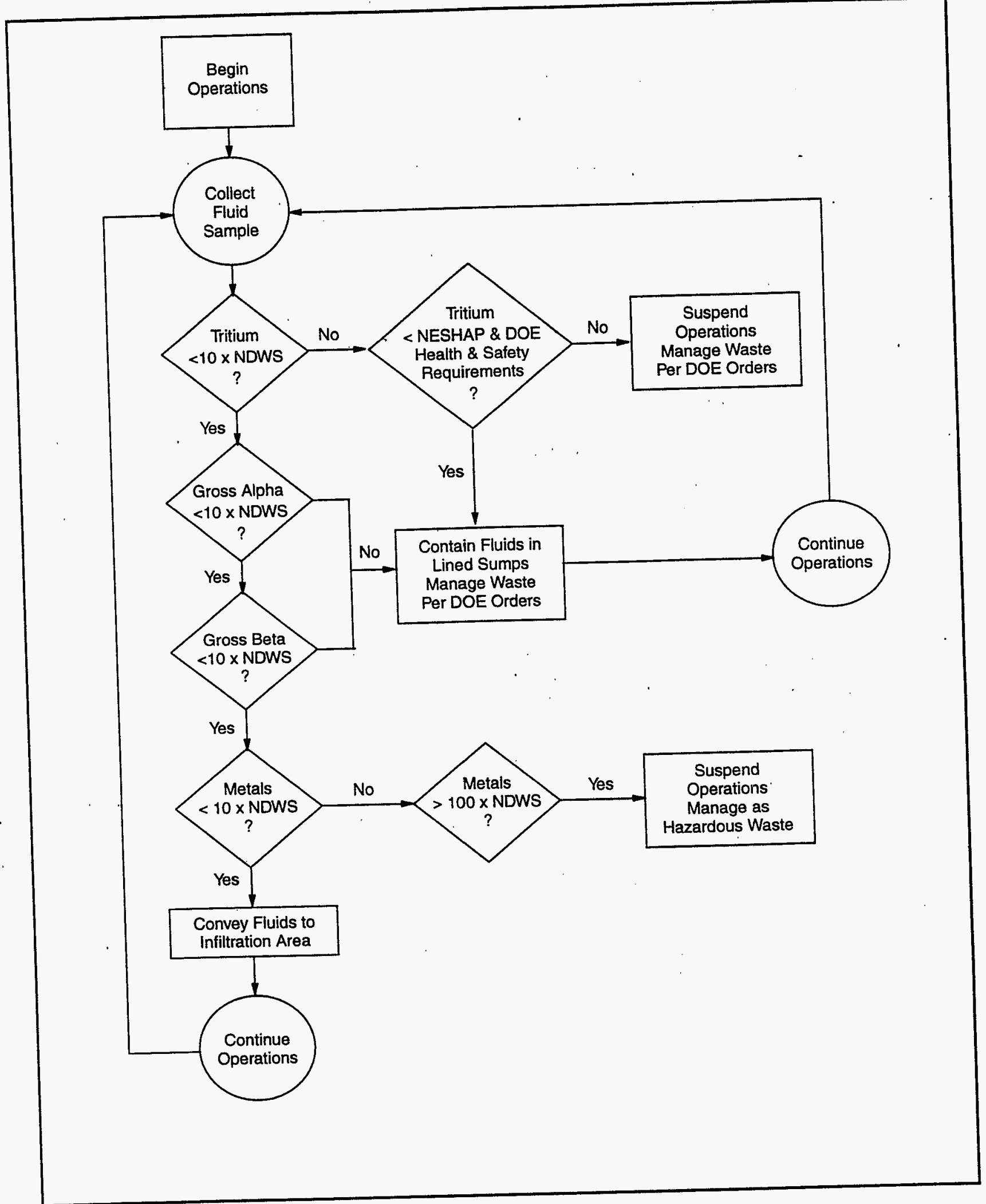

Figure 5-1 
Hazardous and mixed wastes will be properly manifested and transported to a permitted facility within 90 days of generation in accordance with RCRA regulations. Fluids above DOE limits for radiological constituents, but below RCRA limits, will be managed in the lined sump and allowed to evaporate. The associated solids will be transported to an appropriate disposal facility in accordance with the CAIP. If the level of radioactive constituents is great enough that air quality or employee health and safety limits could be exceeded, operations will be suspended and the waste managed as low-level waste in accordance with applicable DOE Orders and state and federal regulations.

A single-lined sump shall be constructed at each well for collection of unsaturated zone fluids and fluids shown, through on-site monitoring, to be below fluid management criteria (i.e., "uncontaminated"). A double-lined sump with a leak detection system will be constructed at each well to contain fluids from saturated zone drilling that are shown through on-site monitoring to exceed fluid management objectives (i.e., "contaminated") as stated in Section 4.0 of this FMP. Fluids meeting fluid quality objectives as stated in Section 4.0 of this FMP may be routed to the ground surface. It is not currently planned that an infiltration area will be constructed. Fluids contained in the double-lined sump that do not meet fluid quality objectives may be routed to other lined sumps or will be contained pending ultimate disposition. 


\subsection{Fluid Management for Routine Monitoring}

Monitoring activities are defined as those routine, scheduled, periodic activities associated with collection of groundwater monitoring samples. In general, groundwater monitoring samples are to be collected annually. Fluid generated from the activities associated with groundwater sampling (such as from purging the well) will be contained in a lined sump unless process knowledge is sufficient to allow for direct routing to an infiltration basin or the ground surface. If fluids are routed to the sump, after the groundwater sampling event has ceased (i.e., no more fluid will be generated by that sampling event), a composite sump sample will be collected and analyzed for the parameters listed in Table 3-1. Six months following the sampling event, if fluid remains in the sump, another composite sump sample shall be collected and analyzed for the parameters listed in Table 3-1. Analytical results shall be reported to the NDEP in accordance with Section 7.0 of this FMP. 


\subsection{Reporting Criteria}

The reporting criteria proposed for meeting the requirements of a general water pollution control permit for environmiental restoration activities consists of the following:

1. Spills, leaks, and releases shall be reported in accordance with state of Nevada regulations. All fluids in excess of ten times the NDWS limits, as provided in Section 4.0 of this plan, that are conveyed to the infiltration area or beyond the confines of the constructed fluid management devices, in excess of 1 cubic meter ( 1 cubic meter of liquid $=264.2$ gallons), shall be reported to the NDEP by telephone (702-486-2866) prior to the end of the next business day following verification of the incident. Oral notification shall be followed by a written report which includes elements described in spill reporting regulations within ten calendar days.

2. NDEP will be notified immediately if laboratory results indicate that mixed or hazardous waste has been generated within any of the lined sumps. Non-emergency actions that constitute deviations to this FMP will be reported to the NDEP prior to implementation of the . action. Emergency actions which are taken that constitute deviations to this FMP will be reported orally to NDEP within 24 hours of implementation of the action and a written report will be provided to NDEP within 10 working days of the action.

3. The fluid management analytical results will be incorporated into the Corrective Action Decision Document which will be provided to NDEP in accordance with milestones established in the FFACO.

4. A report will be sent to the NDEP within nine months of collection of sump samples collected during routine well monitoring activities (see Section 6.0 ). The report will contain:

- Date of sampling .

- Synopsis of laboratory analytical data

All correspondence to the NDEP Regulator shall be addressed to the following:

\section{Program Manager}

Nevada Division of Environmental Protection

Bureau of Federal Facilities

333 W. Nye Lane

Carson City, NV 89710

Program Manager Telephone: (702) 687-4670

Office Telefax: (702) 885-0868

All field and laboratory data generated in support of PSA well construction activities will be archived and made available for inspection by the NDEP Regulator. Copies of interim fluid 
status reports will be forwarded to and maintained at the well site for on-site field inspection. The following data will be generated and retained on file. This data may be made available to the NDEP for inspection upon request:

- Legible copies of daily drilling progress reports and records of daily well-site activities

- Volumetric measurements of fluids generated during each stage of well construction

- Records of make-up water delivery and usage during each stage of well construction

- On-site effluent monitoring data

- Laboratory analytical data with supplemental quality assurance/quality control and chain of custody records

- Records of process materials (cement, grout, casing, screens, packing, drilling fluids) and drilling additive usage, and equipment decontamination

- Records of geological, geotechnical, and hydrological evaluations

- Photographs illustrating site operations, methods, procedures, and progress 


\subsection{References}

AEC, see U.S. Atomic Energy Commission.

DOE, see U.S. Department of Energy.

U.S. Atomic Energy Commission, Nevada Operations Office. 1970. Site Disposal Report, Fallon Nuclear Test Site (Shoal), Churchill County, Nevada, NVO-73. Las Vegas, Nevada.

U.S. Department of Energy, Nevada Operations Office. 1996a. Federal Facility Compliance Agreement and Consent Order. Las Vegas, Nevada.

U.S. Department of Energy, Nevada Operations Office, 1996b. Nevada.Test Site Waste Acceptance Criteria, NVO-325, Rev. 2. Las Vegas, Nevada.

U.S. Department of Energy, Nevada Operations Office; 1996c. Corrective Action Investigation Plan for Project Shoal Area, CAU No. 416. Las Vegas, Nevada. 


\section{Distribution List}

\section{Copies}

Janet Appenzeller-Wing

8

DOE/Nevada Operations Office

P.O. Box 98518

Las Vegas, Nevada 89193-8518 